\title{
ETHYLENE EVOLUTION AND ENDO- $\beta$-MANNANASE ACTIVITY DURING LETTUCE SEED GERMINATION AT HIGH TEMPERATURE
}

\author{
Warley Marcos Nascimento ${ }^{1 *}$; Daniel James Cantliffe ${ }^{2}$; Donald John Huber ${ }^{2}$ \\ ${ }_{2}^{1}$ Embrapa Hortaliças, C.P. 218 - 70359-970 - Brasília, DF - Brasil. \\ ${ }^{2}$ Horticultural Sciences Department, University of Florida, Gainesville, FL 32611-0690 - USA. \\ *Corresponding author 〈wmn@cnph.embrapa.br>
}

\begin{abstract}
High temperatures during lettuce seed imbibition can delay or completely inhibit germination and the endosperm layer appears to restrict the radicle protrusion. The role of endo- $\beta$-mannanase during lettuce seed germination at $35^{\circ} \mathrm{C}$ and the influence of ethylene in endo- $\beta$-mannanase regulation were investigated. Seeds of 'Dark Green Boston' (DGB) and 'Everglades' (EVE) were germinated in water, or $10 \mathrm{mmol} \mathrm{L}^{-1}$ of 1-aminocyclopropane-1-carboxylic acid (ACC), or $10 \mathrm{mmol} \mathrm{L}^{-1}$ of aminoethoxyvinylglycine (AVG), or $20 \mathrm{mmol} \mathrm{L}^{-1}$ of silver thiosulphate (STS). Seeds were also primed in polyethylene glycol (PEG), or PEG + ACC, PEG + AVG, or PEG + STS. Untreated seeds germinated $100 \%$ at $20^{\circ} \mathrm{C}$. At $35^{\circ} \mathrm{C}, \mathrm{EVE}$ seeds germinated $100 \%$, whereas DGB seeds germinated only $33 \%$. Seed priming or adding ACC during incubation increased germination at $35^{\circ} \mathrm{C}$. Higher ethylene evolution was detected in EVE than in DGB during germination at $35^{\circ} \mathrm{C}$. AVG did not inhibit seed germination of DGB at $35^{\circ} \mathrm{C}$, but STS did. Higher endo- $\beta$-mannanase activity was observed in EVE compared with DGB seeds. Providing ACC either during priming or during germination increased endo- $\beta$-mannanase activity, whereas AVG and STS led to decreased or no activity. Ethylene may overcome the inhibitory effect of high temperature in thermosensitive lettuce seeds due to increased endo- $\beta$-mannanase, possibly leading to weakening of the endosperm.

Key words: Lactuca sativa, thermoinhibition, thermodormancy, endosperm weakening, seed priming
\end{abstract}

\section{EVOLUÇÃO DE ETILENO E ATIVIDADE DA ENZIMA ENDO- $\beta$ - MANANASE DURANTE A GERMINAÇÃO DE SEMENTES DE ALFACE SOB ALTAS TEMPERATURAS}

\begin{abstract}
RESUMO: Altas temperaturas durante a embebição das sementes de alface podem atrasar ou inibir a germinação e o endosperma parece ser o responsável na restrição da protrusão da radícula. O envolvimento da enzima endo- $\beta$-mananase durante a germinação de sementes de alface a $35^{\circ} \mathrm{C}$ e a influência do etileno na regulagem desta enzima foram estudados. Sementes das cultivares Dark Green Boston (DGB) e Everglades (EVE) foram germinadas em água ou em soluções de $10 \mathrm{mmol} \mathrm{L}^{-1}$ de 1-aminociclopropano-1- ácido carboxilico (ACC), $10 \mathrm{mmol} \mathrm{L}^{-1}$ de amino-etoxi-vinil-glicina (AVG), ou $20 \mathrm{mmol} \mathrm{L}^{-1}$ de tiossulfato de prata (STS). Sementes foram ainda osmoticamente condicionadas em soluções de polietilenoglicol (PEG), ou PEG + $\mathrm{ACC}, \mathrm{PEG}+\mathrm{AVG}$, ou PEG + STS. Sementes não tratadas germinaram $100 \%$ a $20^{\circ} \mathrm{C}$. A $35^{\circ} \mathrm{C}$, EVE germinou $100 \%$, enquanto DGB germinou somente $33 \%$. A germinação a $35^{\circ} \mathrm{C}$ aumentou em sementes osmoticamente condicionadas ou sementes que receberam ACC durante a incubação. Maior evolução de etileno foi detectada em EVE do que em DGB durante a germinação a $35^{\circ} \mathrm{C}$. AVG não inibiu a germinação de $\mathrm{DGB}$ a $35^{\circ} \mathrm{C}$, enquanto que STS inibiu. Maior atividade de endo- $\beta$-mananase nas sementes foi observada em EVE quando comparado com DGB. Fornecimento de ACC tanto durante o condicionamento osmótico como durante a germinação, aumentou a atividade de endo- $\beta$-mananase, enquanto que AVG e STS proporcionaram um decréscimo ou ausência da atividade enzimática. O etileno pode minimizar o efeito inibitório de altas temperaturas na germinação de sementes de genótipos sensíveis de alface devido ao aumento da enzima endo- $\beta$-mananase, possivelmente levando ao enfraquecimento do endosperma.

Palavras-chave: Lactuca sativa, termo-inibição, termo-dormência, enfraquecimento do endosperma, condicionamento osmótico
\end{abstract}

\section{INTRODUCTION}

High temperatures during lettuce seed imbibition can delay or completely inhibit germination. The lettuce embryo is completely enclosed within an endosperm through which the radicle must penetrate to grow and complete germination. The lettuce endosperm layer appears to restrict radicle protrusion, especially at high temperature (Sung et al., 1998a). Ikuma \& Thimann (1963) proposed that the action of an enzyme produced by the embryo en- 
abled the radicle tip to penetrate through the restricting tissues. They did not isolate or identify the enzyme. Dutta et al. (1997) reported that a cell-wall-bound endo- $\beta$ mannanase was expressed in lettuce seed endosperm prior to radicle protrusion and was regulated by the same conditions that govern seed germination. These authors suggested that endo- $\beta$-mannanase was involved in weakening of the lettuce endosperm cell walls.

Ethylene overcomes the inhibitory effect of high temperature on lettuce seed germination (Abeles, 1986; Abeles \& Lonski, 1969; Burdett, 1972a; Dunlap \& Morgan, 1977; Fu \& Yang, 1983; Huang \& Khan, 1992; Keys et al., 1975; Khan \& Prusinski, 1989; Negm et al., 1972; Rao et al., 1975; Saini et al., 1986; 1989). However, the mechanism of ethylene action during seed germination is not understood. High temperatures $\left(35\right.$ to $40^{\circ} \mathrm{C}$ ) inhibited ethylene production in various plant tissues, such as apple and mung bean (Yu et al., 1980). Burdett (1972b) reported that the pretreatment of seeds at high temperature reduced germination primarily through its inhibitory effect on ethylene production by the seeds. Ethylene is specifically needed for germination of thermosensitive lettuce genotypes at high temperature (Nascimento et al., 2000).

Several authors reported that ethylene synthesis or sensitivity to ethylene action in lettuce was decreased during seed imbibition at high temperature (Abeles, 1986; Burdett, 1972a; Dunlap \& Morgan, 1977; Khan \& Huang, 1988). High temperature stress may inhibit ethylene production and/or action and raise the threshold concentration of ethylene needed for lettuce seed germination. Abeles \& Lonski (1969) however, could not increase germination of thermotolerant lettuce seeds with exogenous ethylene. They could, however, stimulate lettuce seeds to germinate at high temperature before they become thermodormant. However, Burdett (1972a) reported an increase in ethylene production in lettuce seeds as temperature increased from 20 to $30^{\circ} \mathrm{C}$.

Ethylene appears to have a "softening effect" on lettuce endosperm tissue (Abeles, 1986). This author reported that the action of ethylene on lettuce seed germination was the promotion of radicle cell expansion in the embryonic hypocotyl; as the radicle cells expanded they pushed through the endosperm and seed coat.

Ethylene has also been reported to stimulate the synthesis of some enzymes in various species (Cervantes et al., 1994; Hasegawa et al., 1995). Separation of pepper and peach cells in the abscission zones due to the activation of cell wall enzymes, such as endo- $\beta-1,4$-glucanases, was reported as a ethylene effect (Casadoro et al., 1999). Moreover, endo- $\beta$-mannanase was suggested to be regulated by ethylene (Nascimento et al., 1999; 2000).

Based on previous studies and assuming that weakening of the endosperm must occur for lettuce seed to germinate at high temperature (Nascimento et al., 2000; 2001), ethylene might overcome the inhibitory effect of high temperature by activating a cell wall enzyme respon- sible for endosperm digestion. The objective of the present study was to determine the association of ethylene with endo- $\beta$-mannanase activity during lettuce seed germination at high temperature.

\section{MATERIAL AND METHODS}

Plant Material - Lettuce (Lactuca sativa L.) seeds (achenes) from thermosensitive 'Dark Green Boston' (DGB) and thermotolerant 'Everglades' (EVE) genotypes were used in this study. Thermotolerance was defined as the ability of seeds to germinate above $90 \%$ at temperatures up to $35^{\circ} \mathrm{C}$ in the light (Guzman et al., 1992). Genotypes DBG and EVE were chosen because of their genetic relationship (Guzman et al., 1992). All seeds were produced in the same season and region of San Joaquin Valley, California, in 1994. Seeds were stored at $10^{\circ} \mathrm{C}$, $40 \%$ RH prior to use.

Seed Priming - Seeds were primed in $200 \mathrm{~mm}$ test tubes for 3 days at $15^{\circ} \mathrm{C}$ with constant light $\left(\sim 26 \mu \mathrm{mol} \mathrm{m} \mathrm{m}^{-2} \mathrm{~s}^{-1}\right)$ in an aerated solution of polyethylene glycol (PEG), (osmotic potential of $-1.2 \mathrm{MPa})$, or PEG $+10 \mathrm{mmol} \mathrm{L}^{-1}$ of 1-aminocyclopropane-1-carboxylic acid (ACC), or PEG $+10 \mathrm{mmol} \mathrm{L}^{-1}$ of aminoethoxyvinylglycine (AVG), or PEG $+20 \mathrm{mmol} \mathrm{L}^{-1}$ of silver thiosulphate (STS) $(30 \mathrm{~mL}$ of solution per $\mathrm{g}$ of seed). An aquarium pump provided aeration. The air was pre-hydrated by bubbling through water to minimize evaporation from the priming solution. Afterwards, seeds were placed in a Buchner funnel, rinsed three times with $100 \mathrm{~mL}$ of distilled water, and redried in an incubator at $15^{\circ} \mathrm{C}$ and $45 \% \mathrm{RH}$ for 3 days (Nascimento, 1998).

Seed Moisture Content - Seed moisture content was determined by drying seeds for 1 hour at $130^{\circ} \mathrm{C}$. The seeds were then placed in a desiccator at room temperature for 20 min before weighing (AOSA, 1993). Samples were replicated twice.

Seed Germination - Four replications of 25 seeds were placed on two layers of $5 \mathrm{~cm}$ diameter blotter paper (Anchor Paper, Hudson, WI) moistened with $3 \mathrm{~mL}$ of distilled water. Distilled water was added as needed to keep the filter paper moist. Blotters were covered with $5.5 \mathrm{~cm}$ Petri dishes lids and incubated at 20 or $35^{\circ} \mathrm{C}$ under constant light $\left(\sim 26 \mu \mathrm{mol} \mathrm{m} \mathrm{m}^{-2} \mathrm{~s}^{-1}\right)$ on a one-dimensional thermogradient table (Type DB 5000, Van Dok \& De Boer, B.V., Holland). Seeds were also germinated in ACC $\left(10 \mathrm{mmol} \mathrm{L}^{-1}\right)$, AVG $\left(10 \mathrm{mmol} \mathrm{L}^{-1}\right)$, and STS $(20 \mathrm{mmol}$ $\left.\mathrm{L}^{-1}\right)$ solutions. Germinated seeds were counted daily at the same time. In addition, in the first 24 hours, seed germination was observed periodically. Germination rate was calculated according to the formula $\mathrm{S} \mathrm{Ti} \mathrm{Ni} \mathrm{/} \mathrm{S} \mathrm{Ni,} \mathrm{where}$ $\mathrm{Ni}$ is the number of newly germinated seed at time $\mathrm{Ti}$ (Maguire, 1962). 
Enzyme Activity - A gel-diffusion assay (Downie et al., 1994; Still et al., 1997) was used to measure endo- $\beta$ mannanase (EC 3.2.1.78) activity after seed priming and during seed germination. Gel plates were prepared by dissolving $0.05 \%(\mathrm{w} / \mathrm{v})$ galactomannan (locust bean gum, Sigma Chemical Co., St. Louis, MO) in incubation buffer $\left(0.1 \mathrm{~mol} \mathrm{~L}^{-1}\right.$ citric acid, $0.2 \mathrm{~mol} \mathrm{~L}^{-1}$ sodium phosphate, $\mathrm{pH}$ 5.0), stirring and heating for $30 \mathrm{~min}$. Afterward the solution was clarified by centrifugation at $11,000 \mathrm{~g}$ for $15 \mathrm{~min}$ at $4^{\circ} \mathrm{C}$. Phytagar (Gibco Lab., Grand Island, NY) at $0.7 \%$ $(\mathrm{w} / \mathrm{v})$ was added to the clarified solution and stirred and heated to boiling. Thirty $\mathrm{mL}$ of the solution were dispensed into 150 × $25 \mathrm{~mm}$ disposable Petri dishes (Falcon, Franklin Lakes, NJ). After solidification, 32 wells per plate were made using a 2-mm disposable plastic pipette and removing the excised gel by aspiration.

Twenty-eight whole individual endosperms from lettuce seeds imbibed at different temperatures for different periods of time were used on each plate. Radicle protrusion was previously determined in both temperatures for each genotype. Three replications were utilized for each treatment. Endosperms were excised by pressing the cotyledon end using the tip of a conical glass rod. Micropylar and lateral regions were separated with a surgical blade. Each endosperm or endosperm part was placed into an individual microtiter plate (Nalge Nunc, Naperville, IL) well containing $20 \mu \mathrm{L}$ of incubation buffer $\left(0.1 \mathrm{~mol} \mathrm{~L}^{-1}\right.$ citric acid, $0.2 \mathrm{~mol} \mathrm{~L}^{-1}$ sodium phosphate, $\mathrm{pH}$ 5.0) and incubated in the dark for 2 hours at $20^{\circ} \mathrm{C}$.

After incubation, $10 \mu \mathrm{L}$ of buffer from each well was transferred to the gel-diffusion plates and incubated for 24 hours. Petri dishes were covered with lid and wrapped in Parafilm (American National Can., Greenwich, CT). Gels were stained by adding $10 \mathrm{~mL}$ of Congo Red (Sigma Chemical Co., St. Louis, MO) in water $(0.4 \%, \mathrm{w} / \mathrm{v})$ to each plate. Plates were shaken for $20 \mathrm{~min}$ at $60 \mathrm{rpm}$ during staining. The Congo red solution was decanted and the gel was gently washed $(1 \mathrm{~min})$ in distilled water, then $10 \mathrm{~mL}$ of the citrate-phosphate at $\mathrm{pH}$ 7.0 were added. After 2-3 min on an orbital shaker at 60 rpm, the buffer was decanted. Plates were scanned within 5-10 min using a Hewlett Packard Scan Jet 3c/T. The diameters of cleared areas were measured using MacRhizo $^{\mathrm{TM}}$ (Regent Instruments Inc., Quebec, Canada) software. Enzyme activity was calculated from standard curves using regression analysis. Purified endo- $\beta$ mannanase (Megazyme, Ireland) was used as standard.

Ethylene Determination - Three replications of $0.2 \mathrm{~g}$ of dry seeds were placed on two layers of $3.0 \mathrm{~cm}$ diameter germination paper (Anchor Paper, Hudson, WI) which were at the base of $38 \mathrm{~mL}$ volume vials sealed with rubber septa. The seeds in the vials were moistened with $3 \mathrm{~mL}$ of distilled water, and incubated under the same conditions as the standard germination procedures. After
$6,9,12$, and $24 \mathrm{~h}$ of imbibition, ethylene evolution was determined. One $\mathrm{mL}$ gas sample was withdrawn using a gas-tight hypodermic syringe. After sample withdrawal, vials were flushed with air and sealed again for additional sampling. Ethylene was assayed using a gas chromatograph (Hewlett-Packard 5890 Series II) equipped with an alumina column and a flame ionization detector. The carrier gas was nitrogen and the column temperature was $100^{\circ} \mathrm{C}$.

Experimental Design and Statistical Analysis - Ethylene evolution, enzyme activity and germination tests were conducted using a randomized complete block design, using three replications per treatment. Germination percentages were transformed to a square root arc sine basis prior to statistical analysis. Analysis of variance (ANOVA) of data was performed by means of Statistical Analysis System (SAS) software (SAS, 1987). Treatment means were separated by the Duncan Multiple Range test.

\section{RESULTS AND DISCUSSION}

Seeds of thermosensitive 'Dark Green Boston' germinated only $33 \%$ in water at $35^{\circ} \mathrm{C}$, whereas incubation in ACC solution increased seed germination to $92 \%$ (Table 1). In DGB, STS reduced both germination and germination rate in the light at $20^{\circ} \mathrm{C}$ (Table 1). Seeds with ACC began to germinate after $12 \mathrm{~h}$ whereas in water and AVG treatments, germination began after $16 \mathrm{~h}$. At $35^{\circ} \mathrm{C}$, STS completely inhibited germination of DGB seeds, but AVG did not affect seed germination.

ACC, the immediate precursor of ethylene biosynthesis (Yang \& Hoffman, 1984), has been implicated in the alleviation of high temperature on lettuce seed germination (Abeles, 1986; Saini et al., 1986; Khan \& Prusinski, 1989; Huang \& Khan, 1992). Dutta \& Bradford (1994) reported that ACC (via conversion to ethylene) extended the high temperature limit for lettuce seed germination by acting in the embryo to maintain a lower water potential threshold for the initiation of growth as temperature was increased. By doing so, the embryo could grow and push through the endosperm and seed coat.

STS, a putative specific inhibitor of ethylene action, interacts with the binding site for ethylene (Beyer Jr., 1976; Veen, 1983). STS decreased seed germination of DGB at both temperatures, and of EVE at $35^{\circ} \mathrm{C}$. Therefore, ethylene is in fact involved in lettuce seed germination at high temperature and is specifically needed for germination of thermosensitive genotypes (Nascimento et al., 2000).

Abeles (1986) reported that 'Grand Rapids' lettuce seeds germinated approximately $25 \%$ at $30^{\circ} \mathrm{C}$ in the dark, but only $10 \%$ germinated in AVG. Huang \& Khan (1992) reported a reduction of 50\% in germination using AVG during 'Mesa 659' lettuce germination at $35^{\circ} \mathrm{C}$ in the light, and the inhibitory effect of AVG was completely 
reversed by adding ACC. When non-treated lettuce seeds were imbibed at $35^{\circ} \mathrm{C}$, no ACC synthesis was detected. ACC synthase, which converts S-adenosylmethionine (SAM) to ACC, is an important site of control of ethylene biosynthesis (Yang, 1980). ACC synthase, a pyroxidal enzyme, is inhibited by AVG, an inhibitor of all pyridoxal phosphate-dependent enzymes (Yu et al., 1980).

At $20^{\circ} \mathrm{C}$, thermotolerant EVE germinated $100 \%$, even in the presence of AVG and STS (Table 1). At $35^{\circ} \mathrm{C}$, control seeds of EVE germinated $98 \%$ after $12 \mathrm{~h}$ but STS reduced germination to $49 \%$. Germination rate was reduced by STS at $20^{\circ} \mathrm{C}$. Germination in AVG or ACC was the same as the control. Abeles (1986) also found an inhibitory effect of $50 \%$ of STS on seeds germinated at $30^{\circ} \mathrm{C}$ compared to those germinated at $25^{\circ} \mathrm{C}$. In the present study, AVG did not inhibit lettuce germination, possibly because endogenous amounts of ACC were converted to ethylene in the light at high enough levels for germination to occur. AVG, an inhibitor of ethylene synthesis, generally had little influence on lettuce seed germination. For example, germination at $25^{\circ} \mathrm{C}$ (Huang \& Khan, 1992) or $35^{\circ} \mathrm{C}$ (Khan \& Prusinski, 1989) was not inhibited by AVG even though ethylene production was.
Moreover, the concentration of ethylene needed for action was maintained within the embryonic tissues encased by the endosperm and seed coat might have been sufficient to allow seed germination at 20 and $35^{\circ} \mathrm{C}$ in lettuce, even when AVG was added. A critical factor in ethylene studies is the use of inhibitors of ethylene synthesis or action to study germination.

In untreated seeds of DGB at $20^{\circ} \mathrm{C}$, ethylene evolution was first observed during the 9-12 h collection period (Table 2). At $35^{\circ} \mathrm{C}$, ethylene was detected only during the 12-24 $\mathrm{h}$ collection period. Adding ACC led to early detection of ethylene in both genotypes at both temperatures (Tables 2 and 3). AVG completely inhibited ethylene evolution at both temperatures in both genotypes. STS delayed ethylene evolution at both temperatures in both genotypes. Ethylene was detected in EVE during the 9-12 $\mathrm{h}$ imbibition time at either 20 or $35^{\circ} \mathrm{C}$ (Table 3). Previously, EVE was shown to have the ability to produce ethylene during seed germination, even at high temperature (Nascimento et al., 1999; 2000). Prusinski \& Khan (1990) reported that the ability of lettuce genotypes to produce ethylene during high temperature stress generally corresponded with their ability to germinate.

Table 1 - Germination of lettuce 'Dark Green Boston' (DGB) and 'Everglades' (EVE) seeds incubated in different solutions in light at 20 and $35^{\circ} \mathrm{C}$.

\begin{tabular}{|c|c|c|c|c|c|c|c|c|}
\hline \multirow{4}{*}{ Treatment } & \multicolumn{8}{|c|}{ Germination Temperature } \\
\hline & \multicolumn{4}{|c|}{ DGB } & \multicolumn{4}{|c|}{ EVE } \\
\hline & \multicolumn{2}{|c|}{$20^{\circ} \mathrm{C}$} & \multicolumn{2}{|c|}{$35^{\circ} \mathrm{C}$} & \multicolumn{2}{|c|}{$20^{\circ} \mathrm{C}$} & \multicolumn{2}{|c|}{$35^{\circ} \mathrm{C}$} \\
\hline & Total Germ & Germ Rate & Total Germ & Germ Rate & Total Germ & Germ Rate & Total Germ & Germ Rate \\
\hline & $\%$ & $\mathrm{~h}$ & $\%$ & $\mathrm{~h}$ & $\%$ & $\mathrm{~h}$ & $\%$ & $\mathrm{~h}$ \\
\hline Control & $98 \mathrm{a}^{\mathrm{z}}$ & $24 \mathrm{a}$ & $33 \mathrm{~b}$ & $43 \mathrm{a}$ & $100 \mathrm{a}$ & $24 \mathrm{a}$ & 98 a & $24 \mathrm{a}$ \\
\hline $\mathrm{ACC}$ & $100 \mathrm{a}$ & $24 \mathrm{a}$ & $92 \mathrm{a}$ & $38 \mathrm{a}$ & $100 \mathrm{a}$ & $24 \mathrm{a}$ & $100 \mathrm{a}$ & $24 \mathrm{a}$ \\
\hline AVG & $100 \mathrm{a}$ & $24 \mathrm{a}$ & $48 \mathrm{~b}$ & 43 a & $100 \mathrm{a}$ & $24 \mathrm{a}$ & 98 a & $24 \mathrm{a}$ \\
\hline STS & $77 \mathrm{~b}$ & $48 \mathrm{~b}$ & $0 \mathrm{c}$ & $\mathrm{NA}^{\mathrm{y}}$ & $100 \mathrm{a}$ & $25 \mathrm{a}$ & $49 \mathrm{~b}$ & $24 \mathrm{a}$ \\
\hline
\end{tabular}

${ }^{\overline{2}}$ Means within a column followed by the same letter were not different by Duncan's Multiple Range test at $P \leq 0.05$.

${ }^{y}$ No germination.

ACC = aminocyclopropane-1-carboxylic acid, AVG = aminoethoxyvinylglycine, STS = silver thiosulphate.

Table 2 - Ethylene evolution during lettuce 'Dark Green Boston' seed germination in light at 20 and $35^{\circ} \mathrm{C}$.

\begin{tabular}{|c|c|c|c|c|c|c|c|c|}
\hline \multirow{5}{*}{ Treatment } & \multicolumn{8}{|c|}{ Germination Temperature $\left({ }^{\circ} \mathrm{C}\right)$} \\
\hline & \multicolumn{4}{|c|}{20} & \multicolumn{4}{|c|}{35} \\
\hline & \multicolumn{8}{|c|}{ Time of Ethylene Collection (hours) } \\
\hline & $0-6$ & $6-9$ & $9-12$ & $12-24$ & $0-6$ & $6-9$ & $9-12$ & $12-24$ \\
\hline & \multicolumn{8}{|c|}{ Ethylene Concentration } \\
\hline & \multicolumn{8}{|c|}{ nL h ${ }^{1} \mathrm{~g}^{-1}$ seed } \\
\hline Control & $0 \mathrm{~b}^{\mathrm{z}}$ & $0 \mathrm{~b}$ & $25 \mathrm{~b}$ & $64 \mathrm{~b}$ & $0 \mathrm{~b}$ & $0 \mathrm{~b}$ & $0 \mathrm{~b}$ & $5 \mathrm{~b}$ \\
\hline ACC & $21 \mathrm{a}$ & $168 \mathrm{a}$ & $215 \mathrm{a}$ & 542 a & 108 a & 179 a & $250 \mathrm{a}$ & $579 \mathrm{a}$ \\
\hline AVG & $0 \mathrm{~b}$ & $0 \mathrm{~b}$ & $0 \mathrm{c}$ & $0 \mathrm{c}$ & $0 \mathrm{~b}$ & $0 \mathrm{~b}$ & $0 \mathrm{~b}$ & $0 \mathrm{~b}$ \\
\hline STS & $0 \mathrm{~b}$ & $0 \mathrm{~b}$ & $0 \mathrm{c}$ & $18 \mathrm{c}$ & $0 \mathrm{~b}$ & $0 \mathrm{~b}$ & $0 \mathrm{~b}$ & $2 b$ \\
\hline
\end{tabular}

${ }^{2}$ Means within a column followed by the same letter were not different by Duncan's Multiple Range test at $P \leq 0.05$.

$\mathrm{ACC}=$ aminocyclopropane-1-carboxylic acid, AVG = aminoethoxyvinylglycine, $\mathrm{STS}=$ silver thiosulphate. 
Table 3 - Ethylene evolution during lettuce 'Everglades' seed germination in light at 20 and $35^{\circ} \mathrm{C}$.

\begin{tabular}{|c|c|c|c|c|c|c|c|c|}
\hline \multirow{5}{*}{ Treatment } & \multicolumn{8}{|c|}{ Germination Temperature $\left({ }^{\circ} \mathrm{C}\right)$} \\
\hline & \multicolumn{4}{|c|}{20} & \multicolumn{4}{|c|}{35} \\
\hline & \multicolumn{8}{|c|}{ Time of Ethylene Collection (hours) } \\
\hline & $0-6$ & $6-9$ & $9-12$ & $12-24$ & $0-6$ & $6-9$ & $9-12$ & $12-24$ \\
\hline & \multicolumn{8}{|c|}{ Ethylene Concentration } \\
\hline & \multicolumn{8}{|c|}{ nL h"1 $\mathrm{g}^{-1}$ seed $-\mathrm{n}^{-}$} \\
\hline Control & 0 & $0 b^{z}$ & $27 \mathrm{~b}$ & $100 \mathrm{~b}$ & $0 \mathrm{~b}$ & $0 \mathrm{~b}$ & $8 \mathrm{~b}$ & $59 \mathrm{~b}$ \\
\hline $\mathrm{ACC}$ & 0 & $121 \mathrm{a}$ & $253 \mathrm{a}$ & 2048 a & $187 \mathrm{a}$ & $360 \mathrm{a}$ & $643 \mathrm{a}$ & $1716 \mathrm{a}$ \\
\hline AVG & 0 & $0 \mathrm{~b}$ & $0 \mathrm{~b}$ & $0 \mathrm{c}$ & $0 \mathrm{~b}$ & $0 \mathrm{~b}$ & $0 \mathrm{~b}$ & $0 \mathrm{c}$ \\
\hline STS & 0 & $0 \mathrm{~b}$ & $0 \mathrm{~b}$ & $40 \mathrm{c}$ & $0 \mathrm{~b}$ & $0 \mathrm{~b}$ & $0 \mathrm{~b}$ & $3 \mathrm{c}$ \\
\hline
\end{tabular}

${ }^{\mathrm{z}}$ Means within a column followed by the same letter were not different by Duncan's Multiple Range test at $P \leq 0.05$.

$\mathrm{ACC}=$ aminocyclopropane-1-carboxylic acid, AVG = aminoethoxyvinylglycine, $\mathrm{STS}=$ silver thiosulphate.

In the present study, ethylene evolution was not detected under the limits of the experimental procedures when AVG was applied, although germination did occur even at $35^{\circ} \mathrm{C}$. Apparently, either threshold levels for ethylene evolution/action were not detectable (possibly due to restriction of ethylene from the seed coverings, production at lower levels than detectable, or immediate utilization) or ethylene was not absolutely necessary for germination.

When it was detected, ethylene production increased as time of imbibition increased (Tables 2 and 3). Ethylene evolution prior to radicle protrusion was low and not detected before the 9-12 $\mathrm{h}$ collection period in seeds imbibed in water or with ethylene inhibitors (Tables 2 and 3). Several authors (Fu \& Yang, 1983; Saini et al., 1986; Khan, 1994) reported that little or no ethylene was produced before radicle protrusion. In the present study, little or no ethylene was detected in seeds at 16 and $12 \mathrm{~h}$ at 20 and $35^{\circ} \mathrm{C}$, respectively, and relatively large amounts of ethylene were produced at or after radicle protrusion. Perhaps the low amount of ethylene observed prior to radicle protrusion was because ethylene could be "trapped" within the seed by the seed coverings. During radicle protrusion the rupture of endosperm and seed coat might allow release of trapped ethylene. Also, gas exchange may be impaired by the seed coverings, thus reducing ethylene production. Prusinski \& Khan (1990) hypothesized that the lettuce seed coverings might create a hypoxic environment, unfavorable for the conversion of ACC to ethylene.

Ethylene has been reported to regulate synthesis of cell wall enzymes (Casadoro et al., 1999; Moya et al., 1999; Pech et al., 1999). Endo- $\beta$-mannanase was involved in weakening of the lettuce endosperm cell walls at high temperatures (Dutta et al., 1997). Therefore, endo- $\beta$ mannanase activity was assayed during seed germination at $35^{\circ} \mathrm{C}$ (Table 4 ). More endo- $\beta$-mannanase activity was detected prior to radicle protrusion in seeds from thermotolerant EVE than thermosensitive DGB. No endo-
Table 4 - Endo- $\beta$-mannanase activity at 1 hour before radicle protrusion of 'Dark Green Boston' (DGB) and 'Everglades' (EVE) lettuce seeds germinated in light at $35^{\circ} \mathrm{C}$ in water (control), ACC $\left(10 \mathrm{mmol} \mathrm{L}^{-1}\right), \mathrm{AVG}$ $\left(10 \mathrm{mmol} \mathrm{L}^{-1}\right)$, and STS $\left(20 \mathrm{mmol} \mathrm{L}^{-1}\right)$ solutions.

\begin{tabular}{lcc}
\hline & \multicolumn{2}{c}{ Endo- $\beta$-mannanase activity } \\
\cline { 2 - 3 } Treatment & DGB & EVE \\
\hline & $0.0 \mathrm{~b}^{\mathrm{z}}$ & $1.1 \mathrm{~b}$ \\
Control & $1.0 \mathrm{a}$ & $1.7 \mathrm{a}$ \\
ACC & $0.0 \mathrm{~b}$ & $1.0 \mathrm{~b}$ \\
AVG & $0.0 \mathrm{~b}$ & $0.0 \mathrm{c}$
\end{tabular}

$\overline{\mathrm{z}}$ Means within a column followed by the same letter were not different by Duncan's Multiple Range test at $P \leq 0.05$.

$\mathrm{ACC}=$ aminocyclopropane-1-carboxylic acid, $\mathrm{AVG}=$ aminoethoxyvinylglycine, STS $=$ silver thiosulphate.

$\beta$-mannanase activity was detected $1 \mathrm{~h}$ before radicle protrusion when seeds were imbibed in AVG or STS in DGB (Table 4). Perhaps the amount of endo- $\beta$-mannanase activity in those seeds was not enough to be detected by the gel-diffusion assay used in the present study. Conversely, adding ACC during imbibition lead to increased endo- $\beta$-mannanase activity over the control. In EVE, endo- $\beta$-mannanase activity at $35^{\circ} \mathrm{C}$ was associated with $98 \%$ germination in the control and $100 \%$ germination when ACC was added. Lack of endo- $\beta$-mannanase activity $1 \mathrm{~h}$ before radicle protrusion in thermosensitive DGB was associated with 33\% germination in the control. When ACC was added and endo- $\beta$-mannanase activity was detected, $92 \%$ germination was recorded. When STS was added, little or no endo- $\beta$-mannanase activity was detected and little or no germination ensued at $35^{\circ} \mathrm{C}$ in both genotypes.

Seed priming overcomes thermoinhibition and/or thermodormancy of lettuce seeds (Guedes \& Cantliffe, 1980; Cantliffe et al., 1981; Khan, 1980/81). The mechanism of seed priming in thermosensitive lettuce was suggested to result from the weakening of endosperm be- 
cause of increased endo- $\beta$-mannanase activity (Nascimento et al., 2001). A study was thus conducted to investigate whether ethylene could be involved in the weakening of the endosperm. Seeds were primed in solutions of PEG, or PEG + ACC $\left(10 \mathrm{mmol} \mathrm{L}^{-1}\right)$, or PEG + AVG $\left(10 \mathrm{mmol} \mathrm{L}^{-1}\right)$, or PEG + STS $\left(20 \mathrm{mmol} \mathrm{L}^{-1}\right)$.

The original seed moisture content (SMC) of DGB and EVE before priming was 5.9 and $5.6 \%$, respectively. After drying, SMC varied from 4.7 to $6.5 \%$. In DGB, differences in SMC were observed among priming treatments after soaking (data not shown) but probably there was no practical significance to these findings. No radicle protrusion occurred during the priming treatment. During priming, seeds of both genotypes attained approximately $40 \%$ water content after $48 \mathrm{~h}$. Normally these seeds would attain over $100 \%$ increase in fresh weight if soaked in water only. Adding ACC to the priming solution had no significant effect on germination, but the seeds from both genotypes germinated slightly faster than those primed in PEG solutions (Table 5).

Seed germination of both genotypes was decreased by priming in AVG. Huang \& Khan (1992) verified an inhibition of seed germination when AVG was applied during either priming or imbibition but AVG applied only during priming had less of an inhibitory effect on lettuce seed germination presumably because of some absorbency by osmotic solution (Micro-Cel E). They also found more ACC content during germination at $35^{\circ} \mathrm{C}$ in primed seeds compared to non-primed seeds. In addition, the ability of primed lettuce seed to germinate at high temperature was related to high vigor and greater capacity to produce ethylene (Huang \& Khan, 1992).

Priming with STS reduced germination of both genotypes (Table 5). In DGB, priming in PEG + STS completely inhibited subsequent germination at $35^{\circ} \mathrm{C}$, but

Table 5 - Seed germination of lettuce 'Dark Green Boston' (DGB) and 'Everglades' (EVE) after priming, seed dry back, and reimbibition in water in light at $35^{\circ} \mathrm{C}$.

\begin{tabular}{|c|c|c|c|c|}
\hline \multirow{4}{*}{ Priming } & \multicolumn{4}{|c|}{ Genotype } \\
\hline & \multicolumn{2}{|c|}{ DGB } & \multicolumn{2}{|c|}{ EVE } \\
\hline & \multicolumn{4}{|c|}{ Imbibition Time (h) } \\
\hline & 5 & 24 & 5 & 24 \\
\hline PEG & $40 a b^{y}$ & 99 a & $49 \mathrm{a}$ & 99 a \\
\hline $\mathrm{PEG}+\mathrm{ACC}$ & $56 \mathrm{a}$ & $100 \mathrm{a}$ & $50 \mathrm{a}$ & $100 \mathrm{a}$ \\
\hline $\mathrm{PEG}+\mathrm{AVG}$ & $26 \mathrm{~b}$ & $93 \mathrm{~b}$ & $0 \mathrm{~b}$ & $91 \mathrm{~b}$ \\
\hline PEG + STS & $0 \mathrm{c}$ & $0 \mathrm{c}$ & $0 \mathrm{~b}$ & $96 a$ \\
\hline
\end{tabular}

${ }^{\mathrm{z}}$ Means within a column followed by the same letter were not different by Duncan's Multiple Range test at $P \leq 0.05$.

PEG = polyethylene glycol, ACC = aminocyclopropane-1carboxylic acid, AVG = aminoethoxyvinylglycine, $\mathrm{STS}=$ silver thiosulphate.
Table 6 - Endo- $\beta$-mannanase activity at 1 hour before radicle protrusion of 'Dark Green Boston' (DGB) and 'Everglades' (EVE) lettuce seeds primed in PEG solutions, PEG + ACC $\left(10 \mathrm{mmol} \mathrm{L}^{-1}\right), \mathrm{PEG}+\mathrm{AVG}$ $\left(10 \mathrm{mmol} \mathrm{L}^{-1}\right)$, and PEG + STS $\left(20 \mathrm{mmol} \mathrm{L}^{-1}\right)$ and, after dry back, germinated in light at $35^{\circ} \mathrm{C}$ in water.

\begin{tabular}{lcc}
\hline \multirow{2}{*}{ Treatment } & \multicolumn{2}{c}{ Endo- $\beta$-mannanase activity } \\
\cline { 2 - 3 } & \multicolumn{1}{c}{ DGB } & EVE \\
\hline PEG & $1.3 \mathrm{~b}^{\mathrm{z}}$ & $81 \mathrm{ab}$ \\
PEG + ACC & $2.1 \mathrm{a}$ & $100 \mathrm{a}$ \\
PEG + AVG & $1.1 \mathrm{~b}$ & $4.8 \mathrm{c}$ \\
PEG + STS & $0.0 \mathrm{c}$ & $0.0 \mathrm{~d}$ \\
\hline
\end{tabular}

${ }^{2}$ Means within a column followed by the same letter were not different by Duncan's Multiple Range test at $P \leq 0.05$.

PEG = polyethylene glycol, ACC = aminocyclopropane-1carboxylic acid, AVG = aminoethoxyvinylglycine, STS = silver thiosulphate.

only slowed germination in EVE. The beneficial effects of seed priming in alleviating thermoinhibition in thermosensitive lettuce genotypes could thus be negated by the absence of ethylene action. AVG and STS treatments during seed priming led to reduced endo- $\beta$ mannanase activity before radicle protrusion in both genotypes (Table 6). Thus, an increase of endo- $\beta$-mannanase caused by priming was negated by STS. Higher enzyme activity was observed in seeds primed with ACC compared to AVG or STS. An association between ethylene evolution, endo- $\beta$-mannanase activity and seed germination at high temperature was observed.

To conclude on the exact role of ethylene in lettuce seed germination at high temperature, further studies are needed. The use of other specific inhibitors of ethylene action might be a good approach. 1Methylcyclopropane (1-MCP), a gas releasing compound, is a competitive inhibitor of ethylene action, which binds to the ethylene receptor to regulate tissue responses to ethylene (Tian, 1999). In addition, the use of transgenic plants and/or mutants could facilitate the elucidation of the mechanisms of ethylene biosynthesis as well as the role of ethylene in seed germination.

Endo- $\beta$-mannanase might be regulated by ethylene, and that increased endo- $\beta$-mannanase activity before radicle protrusion might contribute to lettuce endosperm weakening, leading to a germination at high temperature. Sung et al. (1998b) reported that seeds from thermotolerant genotypes required less force to penetrate the lettuce endosperm than did thermosensitive genotypes, and suggested that weakening of the endosperm layer of lettuce seeds was a pre-requisite to radicle protrusion at high temperatures. These findings correlated directly with the findings for control of endo- $\beta$ mannanase activity. 


\section{ACKNOWLEDGMENTS}

To the Conselho Nacional de Desenvolvimento Científico e Tecnológico (CNPq) for the scholarship to the corresponding author.

\section{REFERENCES}

ABELES, F.B. Role of ethylene in Lactuca sativa cv. 'Grand Rapids' seed germination. Plant Physiology, v.81, p.780-787, 1986.

ABELES, F.B.; LONSKI, J. Stimulation of lettuce seed germination by ethylene. Plant Physiology, v.44, p.277-280, 1969.

ASSOCIATION OF OFFICIAL SEED ANALYSTS - AOSA. Rules for testing seeds. Journal of Seed Technology, v.16, p.1-113, 1993.

BEYER JR., E.M. A potent inhibitor of ethylene action in plants. Plant Physiology, v.58, p.268-271, 1976.

BURDETT, A.N. Antagonistic effects of high and low temperature pretreatments on the germination and pregermination ethylene synthesis of lettuce seeds. Plant Physiology, v.50, p.201-204, 1972a.

BURDETT, A.N. Ethylene synthesis in lettuce seeds: its physiological significance. Plant Physiology, v.50, p.719-722, 1972b.

CANTLIFFE, D.J.; SHULER, K.D.; GUEDES, A.C. Overcoming seed thermodormancy in a heat sensitive romaine lettuce by seed priming. HortScience, v.16, p.196-198, 1981.

CASADORO, G.; TRAINOTTI, L.; TOMASIN, C.A. Expression of abcission-related endo- $\beta$-1,4-glucanases. EU-TMR-EUROCONFERENCE SYMPOSIUM ON BIOLOGY AND BIOTECHNOLOGY OF THE PLANT HORMONE ETHYLENE, 2 ., Thira (Santorini), Greece, 1998. Proceedings. Dordrecht: Kluwer Academic Publishers, 1999. p.39.

CERVANTES, E.; RODRIGUES, A.; NICOLAS, G. Ethylene regulates the expression of a cysteine proteinase gene during germination of chick pea Cicer arietinum L. Plant Molecular Biology, v.25, p.207-215, 1994

DOWNIE, B.; HILHORST, H.W.M.; BEWLEY, J.D. A new assay for quantifying endo- $\beta$-D-mannanase activity using Congo Red dye. Phytochemistry, v.36, p.829-835, 1994

DUNLAP, J.R.; MORGAN, P.W. Reversal of induced dormancy in lettuce by ethylene, kinetin, and gibberellic acid. Plant Physiology, v.60, p.222224, 1977.

DUTTA, S.; BRADFORD, K.J. Water relations of lettuce seed thermoinhibition: II. Ethylene and endosperm effects on base water potential. Seed Science Research, v.4, p.11-18, 1994.

DUTTA, S.; BRADFORD, K.J.; NEVINS, D.J. Endo- $\beta$-mannanase present in cell wall extracts of lettuce endosperm prior to radicle emergence. Plant Physiology, v.133, p.155-161, 1997

FU, J.R.; YANG, S.F. Release of heat pretreatment-induced dormancy in lettuce seeds by ethylene or cytokinin in relation to the production of ethylene and the synthesis of 1-aminocyclopropane-1-carboxylic acid during germination. Plant Growth Regulator, v.2, p.185-192, 1983.

GUEDES, A.C.; CANTLIFFE, D.J. Germination of lettuce seeds at high temperature after seed priming. Journal of the American Society for Horticultural Science, v.105, p.777-781, 1980.

GUZMAN, V.L.; NAGATA, R.T.; DATNOFF, L.E.; RAID, R.N. 'Florida 202' and 'Everglades': New butterhead lettuce cultivars adapted to Florida. HortScience, v.27, p.852-853, 1992.

HASEGAWA, R.; MARUYAMA, A.; NAKAYA, M.; TSUDA, S.; ESASHI, $Y$. The presence of two types of b-cyanoalanine synthase in germinating seeds and their responses to ethylene. Physiologia Plantarum, v.93, p.713-718, 1995.

HUANG, X.-L.; KHAN, A.A. Alleviation of thermoinhibition in preconditioned lettuce seeds involves ethylene, not polyamine biosynthesis. Journal of the American Society for Horticultural Science, v.117, p.841-845, 1992.

IKUMA, H.; THIMANN, K.V. The role of seed-coats in germination of photosensitive lettuce seeds. Plant Cell Physiology, v.4, p.169-185, 1963

KEYS, R.D.; SMITH, O.E.; KUMAMOTO, J.; LYON, J.L. Effect of gibberellic acid, kinetin, and ethylene plus carbon dioxide on the thermodormancy of lettuce seed (Lactuca sativa L. cv. Mesa 659). Plant Physiology, v.56, p.826-829, 1975.
KHAN, A.A. Hormonal regulation of primary and secondary seed dormancy Israel Journal of Botany, v.29, p.207-224, 1980/81

KHAN, A.A. ACC-derived ethylene production, a sensitive test for seed vigor. Journal of the American Society for Horticultural Science, v.119, p.1083-1090, 1994.

KHAN, A.A.; HUANG, K.-L. Synergistic enhancement of ethylene production and germination with kinetin and 1-aminocyclopropane-1carboxylic acid in lettuce seeds exposed to salinity stress. Plant Physiology, v.87, p.847-852, 1988.

KHAN, A.A.; PRUSINSKI, J. Kinetin enhanced 1-aminocyclopropane-1carboxylic acid utilization during alleviation of high temperature stress in lettuce seeds. Plant Physiology, v.91, p.733-737, 1989.

MAGUIRE, J.D. Seeds of germination-aid in selection and evaluation for seeding emergence and vigor. Crop Science, v.2, p.176-177, 1962.

MOYA, M.A.; MOGGIA, C.; EYZAGUIRRE, J.; JOHN, D.P. Softening in apples and pears. The role of ethylene and several cell wall degrading enzymes. In: EU-TMR-EUROCONFERENCE SYMPOSIUM ON BIOLOGY AND BIOTECHNOLOGY OF THE PLANT HORMONE ETHYLEnE, 2., Thira (Santorini), Greece, 1998. Proceedings Dordrecht: Kluwer Academic Publishers, 1999. p.431-432.

NASCIMENTO, W.M. Involvement of ethylene and endo-beta-mannanase in lettuce seed germination at high temperature. Gainesville, 1998. 138p. Thesis (Doctor) - University of Florida.

NASCIMENTO, W.M.; CANTLIFFE, D.J.; HUBER, D.J. Endo- $\beta$ mannanase activity during lettuce seed germination at high temperature in response to ethylene. In: EU-TMR-EUROCONFERENCE SYMPOSIUM ON BIOLOGY AND BIOTECHNOLOGY OF THE PLANT HORMONE ETHYLENE, 2., Thira (Santorini), Greece, 1998. Proceedings. Dordrecht: Kluwer Academic Publishers, 1999. p.191192.

NASCIMENTO, W.M.; CANTLIFFE, D.J.; HUBER, D.J. Thermotolerance in lettuce seeds: association with ethylene and endo- $\beta$-mannanase. Journal of the American Society for Horticultural Science, v. 125 p.518-524, 2000.

NASCIMENTO, W.M.; CANTLIFFE, D.J.; HUBER, D.J. Endo- $\beta$ mannanase activity and seed germination of thermosensitive and thermotolerance lettuce genotypes in response to seed priming. Seed Science Research, v.11, p.255-264, 2001

NEGM, F.B.; SMITH, O.E.; KUMAMOTO, J. Interaction of carbon dioxide and ethylene in overcoming thermodormancy of lettuce seeds. Plant Physiology, v.49, p.869-872, 1972.

PECH, J.C.; AYUB, R.; LATCHE, A. Ethylene-dependent and ethylene independent pathways in the melon. In: EU-TMREUROCONFERENCE SYMPOSIUM ON BIOLOGY AND BIOTECHNOLOGY OF THE PLANT HORMONE ETHYLENE, 2 ., Thira (Santorini), Greece, 1998. Proceedings. Dordrecht: Kluwer Academic Publishers, 1999. p.105-110.

PRUSINSKI, J.; KHAN, A.A. Relationship of ethylene production to stress alleviation in seeds of lettuce cultivars. Journal of the American Society for Horticultural Science, v.115, p.294-298, 1990

RAO, V.S.; SANKHLA, N.; KHAN, A.A. Additive and synergistic effect of kinetin and ethrel on germination, thermodormancy, and polyribosome formation in lettuce seeds. Plant Physiology, v.56, p.263266, 1975.

SAINI, H.S.; CONSOLACION, E.D.; BASSI, P.K.; SPENCER, M.S. Requirement for ethylene synthesis and action during relief of thermoinhibition of lettuce seed germination by combinations of gibberellic acid, kinetin, and carbon dioxide. Plant Physiology, v.81, p.950-953, 1986.

SAINI, H.S.; CONSOLACION, E.D.; BASSI, P.K.; SPENCER, M.S. Control processes in the induction and relief of thermoinhibition of lettuce seed germination. Actions of phytochrome and endogenous ethylene. Plant Physiology, v.90, p.311-315, 1989.

SAS Institute. SAS/STAT user's guide. Release 6.0. 3.ed. Cary: Statistical Analysis System Institute, 1987.

STILL, D.W.; DAHAL, P.; BRADFORD, K.J. A single-seed assay for endo$\beta$-mannanase activity from tomato endosperm and radicle tissues. Plant Physiology, v.113, p.13-20, 1997.

SUNG, Y.; CANTLIFFE, D.J.; NAGATA, R.T. Seed developmental temperature regulation of thermotolerance in lettuce. Journal of the American Society for Horticultural Science, v.123, p.700-705, 1998a. 
SUNG, Y.; CANTLIFFE, D.J.; NAGATA, R.T. Using a puncture test to identify the role of seed coverings on thermotolerant lettuce seed germination. Journal of the American Society for Horticultural Science, v.123, p.1102-1106, 1998b.

TIAN, M.S. Responses of strawberry fruit to 1-MCP and ethylene. In: EUTMR-EUROCONFERENCE SYMPOSIUM ON BIOLOGY AND BIOTECHNOLOGY OF THE PLANT HORMONE ETHYLENE, 2. Thira (Santorini), Greece, 1998. Proceedings. Dordrecht: Kluwer Academic Publishers, 1999. p.89.

VEEN, H. Silver thiosulphate: an experimental tool in plant science. Scientia Horticulturae, v.20, p.211-224, 1983.
YANG, S.F. Regulation of ethylene biosynthesis. HortScience, v.15, p.238243, 1980.

YANG, S.F.; HOFFMAN, N.E. Ethylene biosynthesis and its regulation in higher plants. Annual Review of Plant Physiology, v.33, p.155-189, 1984.

YU, Y.-B.; ADAMS, D.O.; YANG, S.F. Inhibition of ethylene production by 2,4 dinitrophenol and high temperature. Plant Physiology, v.66, p.286-290, 1980.

Received February 14, 2003

Accepted January 30, 2004 